\title{
FIRST REPORT OF A MARINE DINOFLAGELLATE, ALEXANDRIUM ANDERSONII (DINOPHYACEAE) IN MALAYSIAN WATERS
}

\author{
Roziawati Mohd Razali ${ }^{1, *}$, Chui-Pin Leaw ${ }^{2}$, Hong-Chang Lim³, Mohd Nor Azman Ayub ${ }^{3}$, \\ Masazurah A. Rahim ${ }^{1}$ and Po-Teen Lim $^{2}$ \\ ${ }^{1}$ Fisheries Research Institute Batu Maung, Department of Fisheries Malaysia, 11960 Batu Maung, Pulau Pinang, \\ Malaysia \\ ${ }^{2}$ Bachok Marine Research Station, Institute of Ocean and Earth Sciences, University of Malaya, Bachok, 16310 \\ Kelantan, Malaysia \\ ${ }^{3}$ Faculty of Applied Sciences and Computing, Tunku Abdul Rahman University College, Johor Branch Campus, \\ 85000 Segamat, Johor, Malaysia \\ *Corresponding author: email: roziawati_r80@yahoo.com \\ Received: 13 June 2016 Revised: 13 Oct 2016 Accepted: 2 Nov 2016
}

\begin{abstract}
A field survey was carried out at aquaculture areas of Aman Island, Penang to monitor harmful microalgae. In this study, a strain of Alexandrium species was established in laboratory culture and identified using morphological criteria and nucleotide sequences of the LSU rDNA to confirm the identification. The strain was observed under epi-fluorescence microscope and the morphological characters resembled to the species description of A. andersonii. Based on the nucleotide sequences, the strain also revealed close relationship to A. andersonii. HPLC analysis found that $A$. andersonii was not able to produce paralytic shellfish toxins. This is the first report of A. andersonii found in Malaysian waters.

ABSTRAK Kajian lapangan telah dijalankan di kawasan akuakultur Pulau Aman, Pulau Pinang untuk memantau mikroalga berbahaya. Dalam kajian ini, strain spesis Alexandrium telah dikultur di makmal dan pengesahan identifikasi spesis adalah berdasarkan morfologi dan jujukan nukleotida, LSU rDNA. Strain tersebut diperhati di bawah mikroskop epi-pendarfluor dan didapati ciri morfologinya adalah menyerupai spesis $\underline{\mathrm{A}}$. andersonii. Berdasarkan jujukan nukleotida, strain ini juga didapati mempunyai hubungan rapat dengan $\underline{\mathrm{A}}$. andersonii. Analisa HPLC mendapati bahawa A. andersonii tidak menghasilkan toksin paralitik. Ini merupakan

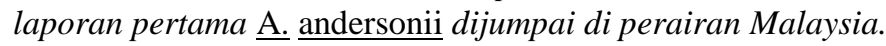

Keywords: Alexandrium, morphology, LSU rDNA, PSP toxins

\section{INTRODUCTION}

Harmful algal bloom (HAB) is a natural phenomenon due to the drastic increase of single species of phytoplankton density in the water column resulting from favorable conditions for growth. Rapid growth of these microalgae causes negative impact to marine ecosystem, human health and mariculture. At present, paralytic shellfish poisoning (PSP) is the only HABrelated shellfish poisoning that had been reported in Malaysia. The first report of shellfish poisoning was documented in Brunei Bay, Sabah in 1976 when the PSP producer, Pyrodinium bahamense var. compressum (Böhm) Steidinger, Tester \& Taylor bloomed and poisoned 202 people, with seven casualties [1]. Subsequently, HABs that involved PSP toxic dinoflagellate, Alexandrium minutum Halim was reported at East Coast of Peninsular Malaysia [2]. In September 2015, selling and collection of the shellfish at Geting River of Kelantan was banned due to the high level of saxitoxin contamination in the shellfish tissue [3].

Paralytic shellfish poisoning is
caused by ingestion of shellfish
contaminated with saxitoxin


produced by toxic dinoflagellate species from the genera Alexandrium Halim, Gymnodinium Stein and Pyrodinium Plate [4, 5]. This biotoxin acts on the mammalian nervous system by blocking the sodium channel and thus preventing the transmission of neuron signal. High levels of PSP can lead to severe illness and death caused by respiratory arrest within a few minutes to a few hours [4].

Aman Island, located in the northern part of the Straits of Malacca, is a very important marine finfish (grouper, snapper and sea bass) aquaculture area and blood cockle farming. The presence of potentially harmful microalgae especially toxin producer in aquaculture areas can pose potential threats to seafood safety and economic losses [6, 7]. Blooms of harmful microalgae can cause massive fish kills in the fish farming areas due to either hypoxia or anoxia in the surrounding environments or excretion of toxic bioactive compounds. Harmful algae bloom can also cause toxin contamination in seafood and this has lead to human intoxication via consumption of contaminated shellfish by toxic microalgae [8]. Thus, the baseline data on the assemblage of potentially harmful microalgae in the area is important to provide further information to the Department of Fisheries for monitoring programs. This could provide additional information on HABs species distribution in the region and contribute to the species inventory for country monitoring purposes.

In this study, a marine dinoflagellate from the genus Alexandrium was morphologically and molecularly characterized. Clonal cultures of Alexandrium were established and morphology of each species was investigated by fluorescence and further analyzed based on the nucleotide sequences of ribosomal DNA genes (rDNA). In contrast to morphological techniques, DNA sequencing methods have improved greatly in recent years, both in terms of accuracy and efficiency, making molecular characterization of cells technically easier and less expensive to perform [9, 10]. Genomic DNA was extracted, and the rDNA was amplified prior to sequencing. The sequences obtained were analyzed and used for phylogenetic reconstruction. The toxicity of the clone was also documented.

\section{MATERIALS AND METHODS}

\section{Isolation and Establishment of clonal cultures}

Phytoplankton samples were collected from Aman Island, Penang during high tide using $20 \mu \mathrm{m}$ mesh size plankton net. Some samples were preserved in Lugol's iodine solution and some were brought back live to the laboratory for cell isolation and culturing. For culturing, individual cell was isolated using a Pasteur pipette with very fine tip. Cells were rinsed a few times in sterile filtered seawater before transferring into a 24-well plate containing sterile filtered seawater. Filtered natural seawater with salinity of 30 PSU was used as medium base. One drop of ESDK medium [11] was added into the wells daily to avoid nutrients depletion. Growth of cells were monitored daily and let to divide for a few weeks. Cells were transferred into sterilized test tubes containing ES-DK medium when reached desired concentration. Cultures were maintained in ES-DK medium at $25^{\circ} \mathrm{C}$ under a light:dark cycle of 16:8. 


\section{Morphology Observation}

Species identification was based on morphology descriptions given by Balech [12, 13] and Fukuyo [14]. Thecal morphology and plate tabulation was observed under an epifluorescence microscope. Fixed samples were stained with $1 \%$ calcofluor white (Fluka, Japan) and viewed under an Olympus IX51 inverted research microscope (Olympus, Tokyo, Japan) at 100× magnification with UV filter sets. Micrographs of each dinoflagellate species were captured with an attached cooled CCD camera and the digital images were analyzed by Analysis ${ }^{\circledR}$ software (Soft Imaging System Inc., USA).

\section{DNA extraction, rDNA amplification and sequencing}

Exponentially growing cultures were pooled and harvested by centrifugation at $3000 \times \mathrm{g}$ for 5 minutes and cell pellets were kept at $-80^{\circ} \mathrm{C}$ until DNA extraction. Genomic DNA was extracted using DNeasy Plant Kit (Qiagen, USA), according to the manufacturer's instruction. The D1/D3 region of the large subunit (LSU) rDNA gene was amplified by polymerase chain reaction (PCR) with primer pair D1R (5'ACCCGCTGAATTTAAGCATA-3') and D3Ca (5'CTTGGTCCGTGTTTCAAGA-3') [15]. The protocol for gene amplification and DNA sequencing were as described previously by Leaw et al. [16, 17]. In brief, PCR was performed with $25 \mu \mathrm{l}$ reaction mixtures, using following program: $4 \mathrm{~min}$ at $94^{\circ} \mathrm{C}$ followed by 35 cycles of $35 \mathrm{~s}$ at $94^{\circ} \mathrm{C}$,
$50 \mathrm{~s}$ at $55^{\circ} \mathrm{C}, 35 \mathrm{~s}$ at $72^{\circ} \mathrm{C}$ and finally an elongation step of $7 \mathrm{~min}$ at $72^{\circ} \mathrm{C}$. The size of the PCR products were estimated by $1 \%$ agarose gel electrophoresis, stained with SYBR Safe DNA Stain (Invitrogen, Life Technologies, Carlsbad, CA, USA) and visualized under UV light. The PCR products were purified using QIAquick purification columns (Qiagen, USA) according to the manufacturer's instructions. The purified products were directly sequenced for both directions by First Base Laboratories (Selangor, Malaysia), using an ABI 377 automated sequencer (PE Applied Biosystems, Foster City, CA, USA). The estimated sequence length from the amplicon was about 900 bp.

\section{Sequences analysis and taxon sampling}

The sequences obtained were then confirmed using BLAST (Basic Local Alignment Search Tool) at NCBI (National Center of Biotechnology Institute). Taxon sampling was performed and selected Alexandrium LSU sequences were retrieved from GenBank Database. A total of 34 taxa were compiled, with Ostreopsis ovata Fukuyo, Ostreopsis sp. and Coolia sp. were used as outgroup. Sequences obtained in this study were deposited in GenBank Database and the details of sequences used for analyses were compiled in Table 1. Only D1/D2 region of the sequence was analyzed. Multiple sequence alignments were performed by using ClustalX [18] and subsequently checked and edited manually using BioEdit [19]. 
Table 1: LSU nucleotide sequences of Alexandrium species obtained in this study and sequences retrieved from Genbank. Cultured strains obtained in this study were in boldface.

\begin{tabular}{|c|c|c|c|}
\hline Taxon & Strain designation & Genbank & Location \\
\hline Ostreopsis ovata & OS-07BR & FM994900 & - \\
\hline Ostreopsis sp. & s0733 & AB674860 & West Pacific Coast, Japan \\
\hline Coolia sp. & CMJJ2 & FR845221 & - \\
\hline A. affine & AS-1 & JF906997 & South China Sea \\
\hline A. affine & JHW0210 & AY438015 & - \\
\hline A. affine & A10 & DQ287852 & - \\
\hline A. affine & AABB0101 & JF521616 & Bell Bay, Tasmania \\
\hline A. affine & AaPA01 & KR188517 & Aman Island, Penang, Malaysia \\
\hline A. concavum & - & AF032348 & North Island, New Zealand \\
\hline A. tamarense & AT-6 & JF906995 & - \\
\hline A. tamarense & JHW0003 & GQ120507 & - \\
\hline A. excavatum & GEV1 & AY056824 & - \\
\hline A. catenella & $\mathrm{ACDH}$ & JF906989 & East China Sea \\
\hline A. catenella & Axsp-K03 & DQ785886 & Jangmok, South Korea \\
\hline A. fundyense & CCMP1719 & JF521624 & New Hampshire, USA \\
\hline A. fraterculus & CAWD97 & AY338750 & New Zealand \\
\hline A. taylori & AY1T & AJ535347 & Italy \\
\hline A. andersonii & CCMP2222 & JF521621 & Tyrrhenian Sea, Italy \\
\hline A. andersonii & CCMP1597 & JF521619 & Massachusetts, USA \\
\hline A. andersonii & CCMP1718 & JF521620 & Massachusetts, USA \\
\hline A. andersonii & AspPA01 & KR188518 & Aman Island, Penang, Malaysia \\
\hline A. ostenfeldii & CCMP1773 & JF21636 & Kattegat, Denmark \\
\hline A. ostenfeldii & IMRV062007 & JF521637 & Flodevigen, Norway \\
\hline A. peruvianum & AP19 & JF921197 & New River, NC, USA \\
\hline A. peruvianum & AP17 & JF921195 & New River, NC, USA \\
\hline A. tamutum & AL2T & EU707459 & - \\
\hline A. insuetum & X6 & AF318233 & Corsica, France \\
\hline A. insuetum & CCMP2082 & JF521630 & Japan \\
\hline A. minutum & AL-1 & JF906999 & Portugal \\
\hline A. minutum & CCMP113 & JF521634 & Ria de Vigo, Spain \\
\hline A. leei & AIMS03 & AY566184 & - \\
\hline A. leei & AT2 & AY959942 & Singapore \\
\hline A. leei & JHW0006-2 & AY438019 & - \\
\hline A. leei & AlPA01 & KR188516 & Aman Island, Penang, Malaysia \\
\hline
\end{tabular}




\section{Phylogenetic analyses}

Phylogenetic analyses of maximum parsimony (MP) and maximum likehood (ML) were performed using Phylogenetic Analysis Using Parsimony* (PAUP*) ver. $4.0 \mathrm{~b} 10$ [20]. A heuristic search and treebisection-reconnection (TBR) swapping with 1,000 bootstrap replications were conducted for the MP analysis. For ML analysis, a substitution and rate heterogeneity model was calculated in jModelTest2 [21] through Akaike information criterion (AIC). ML analysis was then performed in PAUP with 100 random-addition replicates and heuristic searches with stepwise-addition plus TBR branch-swapping and 500 bootstrap replications. Bayesian analysis was performed using MrBayes v3.2.5 [22] with 500,000 Markov chain Monte Carlo (MCMC) generations and 50\% majority rule consensus tree was conducted using a burnin of $25 \%$ and posterior probabilities was calculated.

\section{PSP toxin analysis}

Mid exponential phase cells were harvested in triplicate by centrifugation at $2000 \mathrm{x} g$ for $5 \mathrm{~min}$. Cells were re-suspended in $0.05 \mathrm{M}$ acetic acid and lysed by sonication. The sample was then centrifuged at $10,000 \times \mathrm{g}$ for 10 minutes and subsequently the supernatant was collected. The sample extract was filtered through a $0.45 \mu \mathrm{m}$ nylon membrane filter and the filtrate was analyzed by using HPLC. Analysis of the PSP toxins was carried out using the post column oxidative fluorescence method of Oshima et al. [23]. Liquid chromatography was performed using a Shimadzu UFLC HPLC system fitted with a Pickering post-column reaction system with a fluorescence detector. Toxins were separated by reversed phase chromatography using an Ascentis C18 column $(4.6 \mathrm{~mm}$ i.d. $\mathrm{x} 25 \mathrm{~cm}, 120 \AA, 5 \mu \mathrm{m})$ with a flow rate of $0.8 \mathrm{ml} \mathrm{min} \mathrm{m}^{-1}$. The column temperature was kept at $27^{\circ} \mathrm{C}$, while the post-column temperature was set at $65^{\circ} \mathrm{C}$. All reagents used were of HPLC grade. The chromatographic conditions were performed with mobile phase for STXs consisting of $2 \mathrm{mM}$ heptanesulfonate in $30 \mathrm{mM}$ ammonium phosphate buffer and $6 \%$ acetonitrile (v/v), $\mathrm{pH} 7.1$ and mobile phase for gonyautoxins (GTXs) contained $2 \mathrm{mM}$ heptanesulfonate in $30 \mathrm{mM}$ ammonium phosphate buffer, $\mathrm{pH}$ 7.1. The post-column oxidizing reagent was $7 \mathrm{mM}$ periodic acid in $80 \mathrm{mM}$ sodium phosphate buffer, $\mathrm{pH}$ 9.0, and the acidifier was $0.5 \mathrm{M}$ acetic acid with a flow rate of $0.4 \mathrm{ml} \mathrm{min}^{-1}$. Sample injection volume was $10 \mu \mathrm{l}$. The monitoring of fluorescence was observed at $330 \mathrm{~nm}$ excitation and $390 \mathrm{~nm}$ emissions. PSP toxin profile was identified and quantified by comparing chromatograms of certified toxins standards (NRC, Halifax, Canada).

\section{RESULT AND DISCUSSION}

Some dinoflagellates of the genus Alexandrium Halim are known to produce neurotoxin saxitoxin and its' congeners that causes paralytic shellfish poisoning (PSP). Three Alexandrium species have been implicated in paralytic shellfish poisoning (PSP) incidents in Malaysia, namely Pyrodinium bahamense var. compressum, Alexandrium tamiyavanichii Balech and $A$. minutum [2, 24-25]. The identification of species within Alexandrium was based on fine details of the thecal plates pattern such as shape and size of first apical plate (1), sixth precingular $\left(6^{\prime}\right)$, anterior sulcal (s.a.) and posterior sulcal plate (s.p), the presence and location of the ventral pore (v.p) [13]. In this study, three clonal cultures of Alexandrium species were established from 
Aman Island, Penang, Malaysia. The species were identified as Alexandrium leei Balech, A. affine (Inoue and Fukuyo) Balech and $A$. andersonii Balech. The morphology of the collected Alexandrium leei and A. affine resembled with those previously documented in Strait of Malacca [25]. This represents a new record of $A$. andersonii species occurrence in Malaysia.

\section{Morphology characterization of Alexandrium andersonii}

Cells are non-chain forming, round to slightly oval in shape and small sized species (Figure 1A \& 1B). Cells were 14-25 $\mu \mathrm{m}$ long and 16-24 $\mu \mathrm{m}$ wide. Our observed found that the cells have relatively thin thecal plate, easily collapsed. First plate (1) is narrow with small ventral pore, adjacent to a characteristic s.a and characteristic 6" (Figure 1B). Plate $2^{\prime}$ comparatively broad (Figure 1C). Plate $3^{\prime}$ is hexagonal and almost symmetric (Figure 1C). The 6" plate is arrow-shaped left margin and the s.a is trapezoidal (Figure 1B). A ventral pore was located midway on the right margin of $1^{\prime}$ (Figure 1B), although sometimes it was observed inside 1' (Figure 1C). The posterior sulcal plate (s.p) is wider than long (Figure 1D). The descriptions reported here agree well with the original description of $A$. andersonii from coastal waters off Cape Cod on the Atlantic coast of North America [12]. Alexandrium andersonii is one of the members in A. minutum group [13]. The features of the species (A. minutum, $A$. lusitanicum, $A$. angustitabulatum and $A$. andersonii) in A. minutum group are small size, predominantly oval shape and posterior sulcal plate is wider than long, not quite symmetrical [13]. Alexandrium andersonii is clearly distinguished with the other species in genus by the shape of plate $6^{\prime \prime}$ and s.a plate [13, 24-26]. Based on Figure 2, A. andersonii was shown to be closely related to $A$. ostenfeldii and $A$. peruvianum phylogenetically. In contrast to $A$. andersonii that is in A. minutum group, $A$. ostenfeldii and $A$. peruvianum were placed in the ostenfeldii group by Balech [13] with medium to large cell-size; narrow 1' and very oblique with large ventral pore. The distinct morphological features that can readily differentiate $A$. andersonii with $A$. ostenfeldii and $A$. peruvianum were cell size and characteristic of ventral pore between 1' plate [13, 27, 28]. Other than Malaysia, Alexandrium andersonii was also been found in the Irish coastal waters [27], Gulf of Naples, Italy [29], Aegean Sea, Greece $[26,30]$ and along the coast of China [31]. 

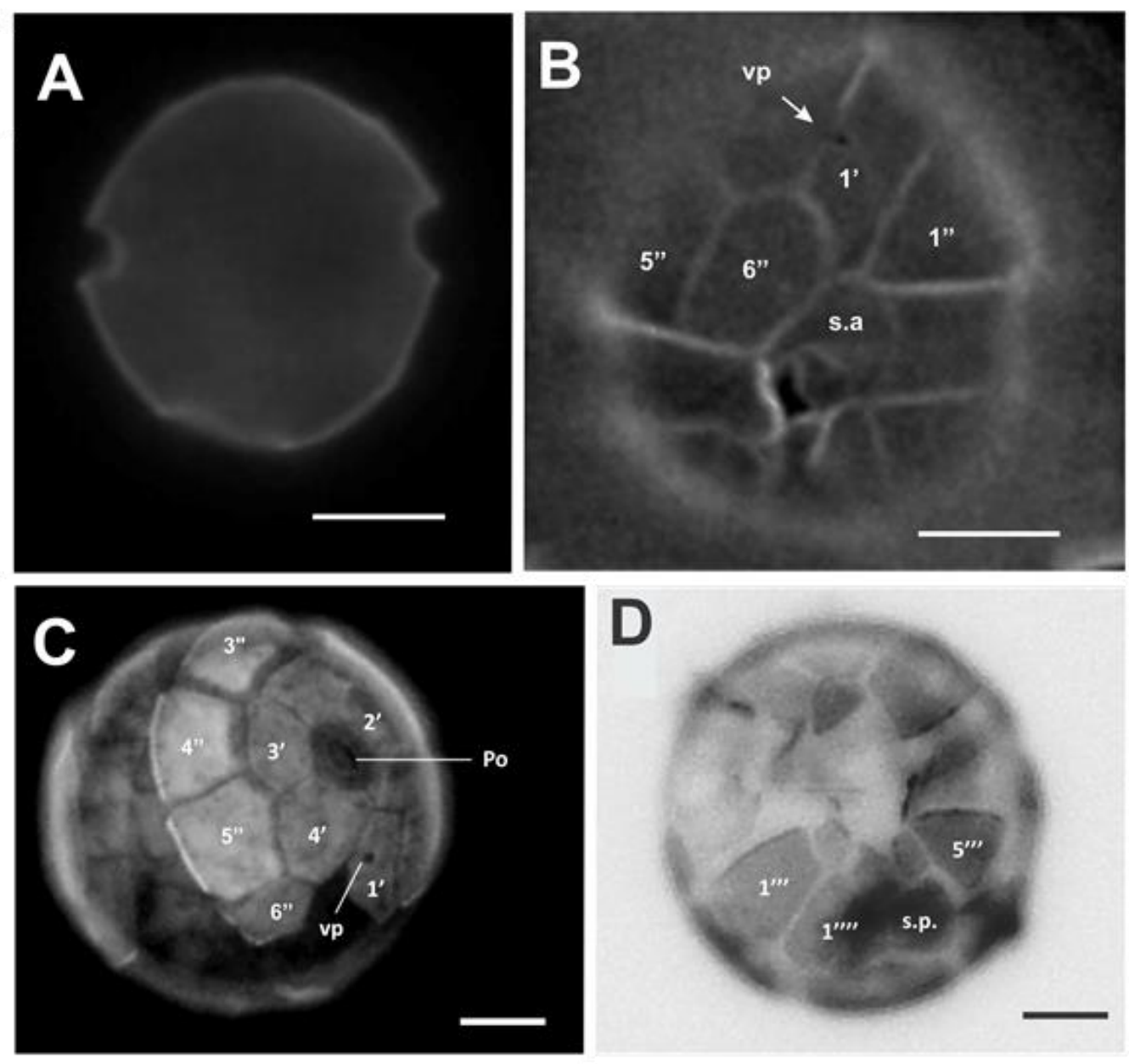

Figure 1: $\quad$ Alexandrium andersonii. (A) a roundish vegetative cell; (B) ventral view of a cell showing the first apical plate (1), precingular plates $1^{\prime \prime}, 5^{\prime \prime}$ and arrow-shaped of sixth precingular plate $\left(6^{\prime \prime}\right)$, location of the ventral pore (v.p) (arrow) and wide anterior sulcal plate (s.a); (C) the apical view showing apical pore (Po), apical plates 1'- 4', precingular plates 3"'- 6"' and v.p inside the 1' plate; (D) antapical view showing sulcal plate (s.p), postcingular plates $1^{\prime \prime \prime}$ and $5^{\prime \prime \prime}$ and antapical plate 1 "'". Scale bars $=10 \mu \mathrm{m}$. 
Molecular phylogeny of Alexandrium species

A total of 565 characters (including gaps) were obtained from the aligned sequences, of which 95 were constant, 297 were parsimony informative and 173 variable characters were parsimony uninformative. Based on the nucleotide sequences of the LSU rDNA, AaPA01 strain grouped together with other A. affine, AlPA01 grouped together with other A. leei, both highly supported by bootstraps and posterior probabilities (MP/ML/BI: 100/100/1.0 and 100/100/0/99, respectively) (Figure 2). The strain of AspPA01 revealed close relationship to other $A$. andersonii with strong node support (MP/ML/BI, 100/100/1.00) (Figure 2) 


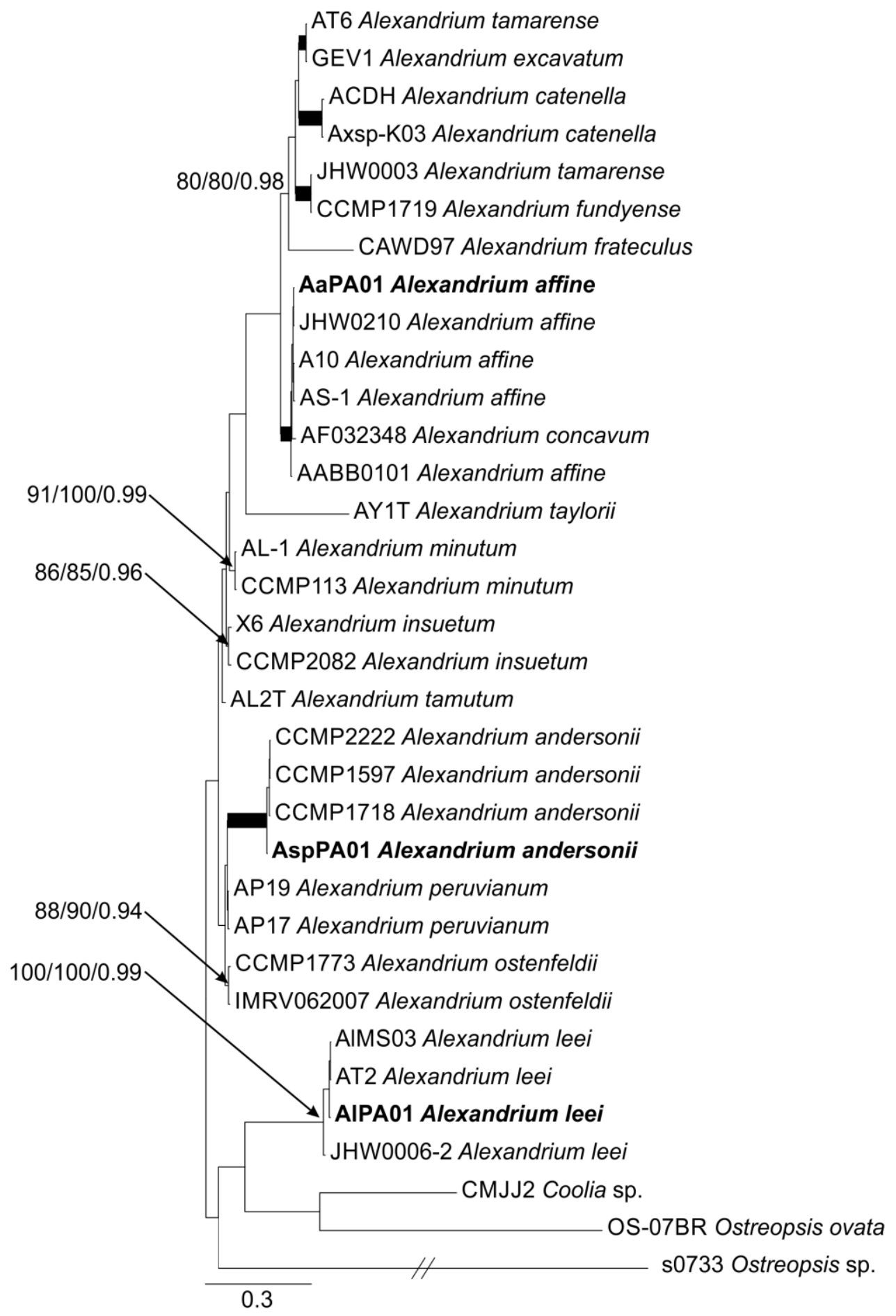

Figure 2: $\quad$ Pylogenetic tree inferred from Bayesian Inference (BI) of Alexandrium species based on LSU rDNA sequences. Alexandrium strains obtained from Aman Island were in boldface. Nodes are annotated with MP/ML bootstrap values of $>80 \%$ and BI posterior probabilities of $>0.90$. 


\section{PSP toxin}

In this study, PSP toxin was not detected from the cultured strain of $A$. andersonii (AspPA01); similarly, it was found to be non-toxic based on previous records $[14,29$, 31]. In contrast, $A$. andersonii from the Gulf of Naples, Italy was found positive for PSP which also consists of saxitoxin (STX) and neosaxitoxin (neoSTX) [29]. However, Sampedro et al., [32] further proved that the same strain from Gulf of Naples, Italy was non-toxic.

\section{CONCLUSION}

The occurrence of Alexandrium andersonii was recorded for the first time in Malaysian waters. The presence of the potentially toxins-producing microalgae in the aquaculture area especially in the cockles farming is alarming even though in low concentration, it may pose a potential threat. Factors contributing to the abundance and occurrence of the potentially harmful microalgae in Aman Island are also required for further investigation. Thus, regular monitoring of plankton in the aquaculture area of Aman Island is essential to ensure that cockles harvested from the area are safe to consume. Molecular data obtained from this study for species of Alexandrium will serve as the preliminary data for DNA barcoding of the potentially harmful dinoflagellates.

\section{ACKNOWLEDGEMENTS}

This work was funded by the Malaysian Government through the Ministry of Science, Technology and Innovation (MOSTI) ScienceFund (02-03-06-SF0011) and Department of Fisheries Malaysia.

\section{REFERENCES}

1. Roy R.N. (1997). Red tide and outbreak of paralytic shellfish poisoning in Sabah. Medical Journal of Malaysia 31: 247-251.

2. Lim, P.T., Leaw, C.P. and Usup, G. (2004). First incidence of paralytic shellfish poisoning of the east coast of Peninsula Malaysia. In: Phang, S.M., Chong, V.C. Ho. S.S., Mokhtar, N., Ooi, J.L.S. (eds), Marine Science into the New Millennium: New Perspectives and Challenges. University of Malaya, Maritime Research Center, Kuala Lumpur, Malaysia, pp. 661-667.

3. Borneo Post Online. 21 September. (2015). Kelantan bans sale of shellfish from Sg. Getting.

4. Backer L.C., Fleming L.E., Rowan A.D. and Baden D.G. (2003). Epidemology, public health and human disease associated with hamful marine algae. In: Manual on Marine Microalgae. Monographs on Oceanic Methodology 11 (eds: Hallegraeff G.M., Anderson D.M. and Cambella A.D.) UNESCO Publishing, Paris, pp. 723-749.

5. Ibrahim M.A.M. (2007). Review of the impact of harmful algae blooms and toxins on the world economy and human health. Egyption Journal of Aquatic Research 33(1): 210-223.

6. Shumway S.E. (1990). A review of the Effects of Algal Blooms on Shellfish and Aquaculture. Journal of the World Aquaculture Society 21 (2): 65-104.

7. Hallegraeff G.M. (1993). A review of harmful algal blooms and their apparent global increase. Phycologia 32: 79-99. 
8. Visciano P., Schirone M., Berti M., Milandri A., Tofalo R. and Suzzi G. (2016). Marine biotoxins: occurrence, toxicity, regulatory limits and reference methods. Frontiers in Microbiology 7: 1051.

9. Litaker R.W., Vandersea M.W. and Kibler S.R. (2007). Recognizing dinoflagellate species using ITS rDNA sequences. Journal of Phycology 43: 344-355.

10. Galluzzi L., Penna A., Bertozzin, E., Vila M., Garces E. and Magani, M. (2004). Development of real-time PCR assay for rapid detection and quantification of Alexandrium minutum (a dinoflagellate). Applied and Environmental Microbiology 70: 1199-1206.

11. Kokinos J.P. and Anderson D.M. (1995). (= L. machaerophorum). Palynology 19: 143-166.

12. Balech E. (1990). Four new dinoflagellates. Halgolander Meeresunters. 44: 387-396.

13. Balech E. (1995). The genus Alexandrium Halim (Dinoflagellata). Sherkin Island Marine Station Special Publication, Cork, Ireland, pp. 1-151.

14. Fukuyo Y. (2001). Research on the ecology and taxonomy of PSP toxinproducing Alexandrium. Asian Biological Resource and Environment Research Center, Tokyo University, pp. 17.

15. Scholin C.A., Anderson D.M. and Sogin M.L. (1993). Two distinct small-subunit ribosomal RNA genes in the North American toxic dinoflagellate Alexandrium fundyense (Dinophyceae). Journal of Phycology 29: 209-216.

16. Leaw C.P., Lim P.T., Ahmad A. and Usup G. 2001. Genetic Diversity of Ostreopsis ovata (Dinophyceae) from Malaysia. Marine Biotechnology 3: 246-255.

17. Leaw C.P., Lim P.T., Kok-Wah Cheng B.K.N. and Usup G. (2010). Morphology and molecular characterization of a new species of thecate benthic dinoflagellate, Coolia malayensis sp. nov. (Dinophyceae). Phycological Society of America 46: 162-171.

18. Thompson J.D., Gibson T.J., Plewniak F., Jeanmougin F. and Higgins D.G. (1997). The ClustalX windows interface: flexible strategies for multiple sequence alignment aided by quality analysis tools. Nucleic Acids Research 25: 48764882.

19. Hall T.A. (1999). BioEdit: a userfriendly biological sequence alignment editor and analysis program for Windows 95/98/NT. Nucleic Acids Symposium Series 41: 95-98.

20. Swofford D.L. (2000). PAUP*: phylogenetic analysis using parsimony (* and other methods). Version 4.0b10. Sinauer Associates, Sunderland, Massachusetts, USA.

21. Darriba D., Taboada G.L., Doallo R., Posada D. (2012). jModelTest 2: more models, new heuristics and parallel computing. Nature Methods 9: 772 .

22. Ronquist F., Huelsenbeck J.P. (2003). MrBayes version 3.0: Bayesian phylogenetic inference under mixed models. Bioinformatics 19: $1572-1574$.

23. Oshima Y. (1995). Postcolumn derivatization liquid chromatography method for paralytic shellfish toxins. Journal of AOAC International 78:528-532.

24. Usup G., Leaw C.P. and Asmat A. (2002a). Increasing important of 
harmful algal blooms in Malaysia. In: Proceedings of the Regional Symposium on Environment and Natural Resources (eds: Omar R., Ali Rahman Z., Latiff M.I., Lihan I. and Adam J. H.) Kuala Lumpur, pp. 144-153.

25. Usup G., Leaw C.P., Asmat A. and Lim P.T. (2002b). Alexandrium (Dinopyhceae) species in Malaysian waters. Harmful Algae 1:265-275.

26. Lilly E.L., Halanych K.M. and Anderson D.M. (2005). Phylogeny, biogeography, and species boundaries within the Alexandrium minutum group. Harmful Algae 4(6): 1004-1020.

27. Touzet N., Franco J.M. and Raine R. (2008). Morphogenetic diversity and biotoxin composition of Alexandrium (Dinophyceae) in Irish coastal waters. Harmful Algae 7:782797.

28. Leaw C.P., Lim P.T., Ng B.K., Cheah M.Y., Ahmad A. and Usup G. (2005). Phylogenetic analysis of Alexandrium species and Pyrodinium bahamense (Dinophyceae) based on theca morphology and nuclear ribosomal gene sequence. Phycologia 44(5): 550-565.
29. Ciminiello P., Fattorusso E., Forino M. and Montresor M. (2000). Saxitoxin and neosaxitoxin as toxic principles of Alexandrium andersonii (Dinophyceae) from the Gulf of Naples, Italy. Toxicons 38: 18711877.

30. Penna A., Fraga S., Maso M., Giacobbe M.G., Bravo I., Garces E., Vila M., Bertozzini E., Andreoni F., Luglie A. and Vernesi C. (2008). Phylogenetic relationships among the Mediterranean Alexandrium (Dinophyceae) species based on sequences of $5.8 \mathrm{~S}$ gene and Internal Transcript Spacers of the rRNA operon. European Journal of Phycology 43(2): 163-178.

31. Gu H., Zeng N., Liu T., Yang W., Muller A. and Krock B. (2013). Morphology, toxicity, and phylogeny of Alexandrium (Dinophyceae) species along the coast of China. Harmful Algae 27: 68-81.

32. Sampedroa N., Franco J.M., Zapatab M., Riobób P., Garcésa E., Pennad A., Caillaude A., Diogènee J., Cachof E. and Campa J. (2013). The toxicity and intraspecific variability of Alexandrium andersonii Balech. Harmful Algae 25:26-38. 